Historic, Archive Document

Do not assume content reflects current scientific knowledge, policies, or practices. 


\section{CAT ALOGUE}

OF THE

FRANKLIN FORESTRY COMPAN Y

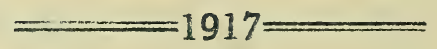

RUSSELL S, LANGDELL, President WALTER L. DANE, Vice-PresIdent HARRY F. GOULD. Treasurer

4

BOSTON OFFICE

89 STATE STREET

Telephone Main 2800

急

BRANCH OFFICES

W ATERTOWN, MASSACHUSETTS

KENNEBUNK, MAINE

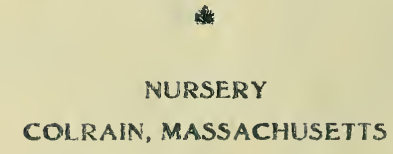

COLRAIN, MASSACHUSETTS

Our specialty is the guaranteed planting under contract of forest nursery stock raised in our own nursery. 


\section{Contract Planting}

14

TWO principal factors essential to the success of a forest plantation are:

First, good stock to start with, especially stock with a well developed root-system; and

Second, some method of caring for this stock after it has been planted and during its first years in the new location.

\section{Reasons for a Guarantee}

The first of these requirements we meet by raising our trees at an altitude which forestalls various diseases. (No disease of any kind has ever been found in our nursery) ; and the second by an ironclad guarantee to replace all trees which may die, to the extent of $75 \%$ of the original planting.

This guarantee has been lived up to in every instance even though this entailed a loss on a given piece of work, and is as fair as we know how to make it. It is attached to and becomes part of every regular contract entered into by us, and is printed in full on the following page.

\section{Special Guarantee}

We are this year continuing our three-year guarantee to satisfy the demands of our clients, nearly $20 \%$ of whom cho se it during the past year in preference to the one year.

This guarantee is similar in all respects to the one year, with the exception of the longer time-limit, and applies to plantations made with either 4-year White pine or 4-year Red Pine transplants, amounting in effect to insurance on such plantations.

\section{Prices}

Prices under all forms of guarantee will be found on pages 4 and 5 of this catalogue. 


The FRANKLIN FORESTRY COMPANY
hereby makes the following guaranty with the party of
the second part named in the above contract, to which
this guarantee is attached and of which it becomes a part:
If after three months and within one year from the
completion of the planting work prescribed by said con-
tract, written notice from said party of the second part
or his legal representatives shall be received at the
principal business office of said Company, to the effect
that less than $75 \%$ of the trees planted under said con-
tract are then alive, then said FRANKLIN FOR-
ESTRY COMPANY shall, at its own expense, make
an examination of such planting or plantings, and if, in
its judgment, the condition so reported exists, the Com-
pany shall, within a period of 18 months from the
completion of the said planting, plant a sufficient number
of trees ( of the same variety and age as the original
planting, if possible) to bring the total number of living
trees up to at least $75 \%$ of the original setting; this work
to be done at no expense whatever to the party of the
second part.

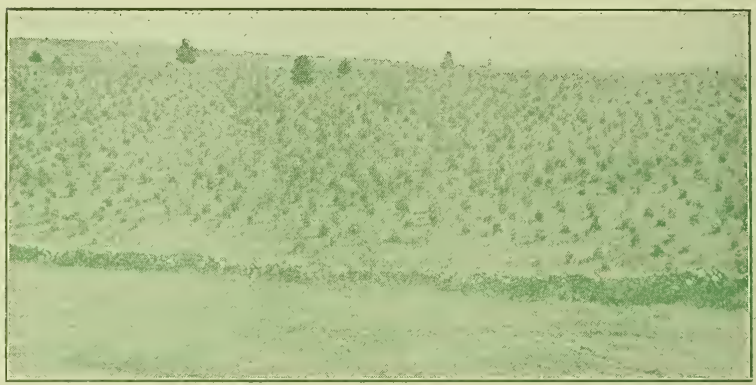

It is hereby expressly understood and agreed that this guaranty shall not apply in case of loss due to fire; nor in case of loss due to convulsions of nature such as landslips, floods, cyclones, or hail storms; nor in case of loss due to any appearance, development, or increase of insect enemies or fungous diseases, except when such insects or fungi were plainly present on the stock when it was originally planted; nor shall it apply in case of loss or damage caused by third parties, whether man or beast, nor in case of loss or damage due to the acts or omissions of the party of the second part, his agent or augents.

But that it shall apply only in case of losses caused by unfavorable and extreme climatic conditions, such as heat, cold, drouth, or early or late frosts.

The Company further guarantees that no weak or inferior stock shall be used in any planting, and that the trees at the time of setting shall be free from injurious insects or diseases. All stock set by the Company bears the certificate of the State Nursery Inspector.

FRANKLIN FORESTRY COMPANY

$$
\text { by }
$$




\section{Early Orders Desirable}

Owing to the fact that all planting work must be planned a good bit in advance, customers are urged to enter their orders before the planting season commences, or at the latest by April 1st, in order to lessen the inevitable rush due to the seasonal character of our work.

\section{Examinations without Charge}

The proper size to use is a matter best determined by personal examination, and all reasonable examinations of this sort will be made with pleasure and without entailing either obligation or expense upon the owner.

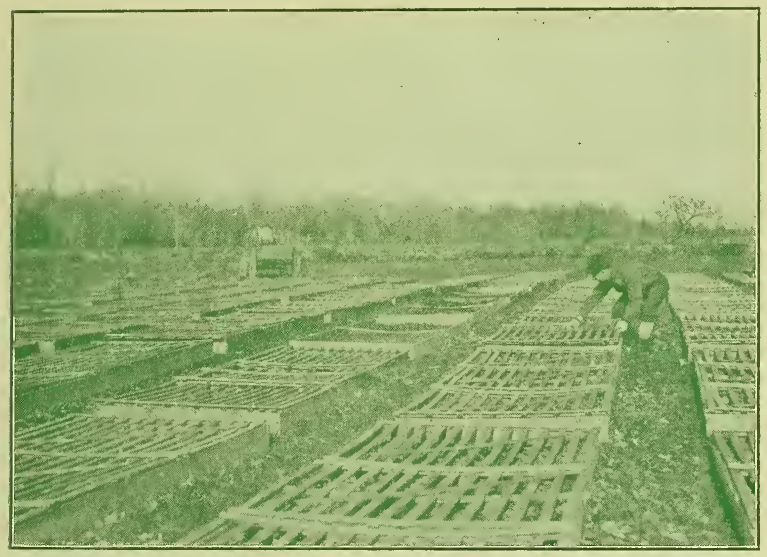

Lath Screens for Protecting the Little Trees

\section{Time to Plant and Stock to Use}

Forest planting may be done at any time when there is no frost in the ground, with the exception of the summer months when the new growth is too tender to stand shipment, the success of the plantation depending not so much upon the time when it is made as on the immediately subsequent rainfall. Wet seasons make successful plantations, whether spring or fall.

Any of the sizes listed on pages four and five will give good results if used on the location best suited to it. Three-year transplants do well under favorable conditions and are the youngest that may be used. Four-year transplants have stronger roots and grow in poorer locations, particularly in grass lands. Still older stock serves special uses, either ornamental or when a better showing is wanted in the beginning. 



\section{Contract Planting Prices-19I7}

Land will be set with the following-named species at the rate of approxtmately 1000 plants to the acre. spaced about $6 \frac{1}{2}$ feet apart cach way. Other spacings at increascd rates.

No parcel less than five acres in area accepted at these prices.

Trees will be set by the thousand unless it is specifically desired to set by the acre, in which case accurate estimate of area must be furnished; if not furnished, land will be surveyed by us at a nominal charge.

3-year transplants of any of the following species CUARAN FEED FOR ONE YEAR as shown on page 2:WHITE PINE, RED PINE, SCOTCH PINE, NORWAY SPRUCE

One species only:

5 to 25 actes. . .....

. 17.00 " $"$

100 acres and upward ............. $16.00 \quad \cdots$
Any two species in mixtule;

5 to 25 acies................ $\$ 20.00$ per thousand

25 10 $100 \cdots \ldots \ldots \ldots$.

100 acres and upward $\ldots \ldots \ldots \ldots \ldots 18.00$

t-year transplants of any of the following species GUARANTEED FOR ONE YEAR as shown on page 2:-

\section{WHITE PINE, RED PINE, SCOTCH PINE, WHITE ASH}

One species only:

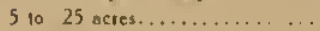

25 to 100 . . . . . . . . . . . . .

100 acies and upwaid
$\$ 23.00$ per thousand

22.00 " "

21.00
Any two species in mixtule:

5 to 25 actes.............. $\$ 25.00$ per thausand

25 to 100 " ................. 24.00 ". ".

100 acies and upwaid $\ldots \ldots, \ldots \ldots, 23.00$ "

SPECIAL

4-year White Pine transplants GuARANTEEd for THREE YEARS

4-year Red Pine transplants Guaranteed for Three YeArs

One species only:

5 to 25 acres............... $\$ 28.00$ pet thousand

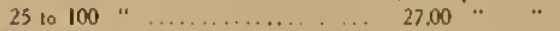

100 acres and upwand $\ldots \ldots \ldots \ldots \ldots \ldots 26.00$ * *.
Bolh species in mixture:

5 to 25 acres.............. \$30.00 per thousand

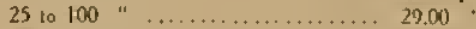

100 ncies and upward $\ldots \ldots \ldots \ldots \ldots, 28.00$

5-year transplants of any of the following species GUARANTEED FOR ONE YEAR as showil on page 2:WHITE PINE, RED PINE, SLOOTCH PINE, JACK PINE

One species only:

1000 trees and up.................... . each
Any two species in mixture:

1000 trees and up .8c. $\mathrm{cach}$

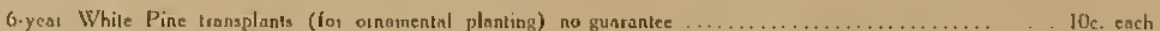

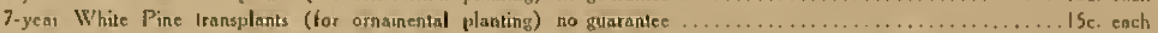

The above prices supersede all previous lists and apply in the New England States only.

Special prices are made for work outside New England. 


\section{Forest Thinning and Surveying THINNING AND FIRE-LINES}

The importance of thinning and fire-lines as means of improving and protecting forest growth is becoming widely recognized. We do this work, furnishing men, tools, and supervision, and financing the jobs ourselves if desired, rendering bills either bi-weekly or monthly.

Examinations and estimates of the probable cost of individual jobs are made gladly and at minimum cost.

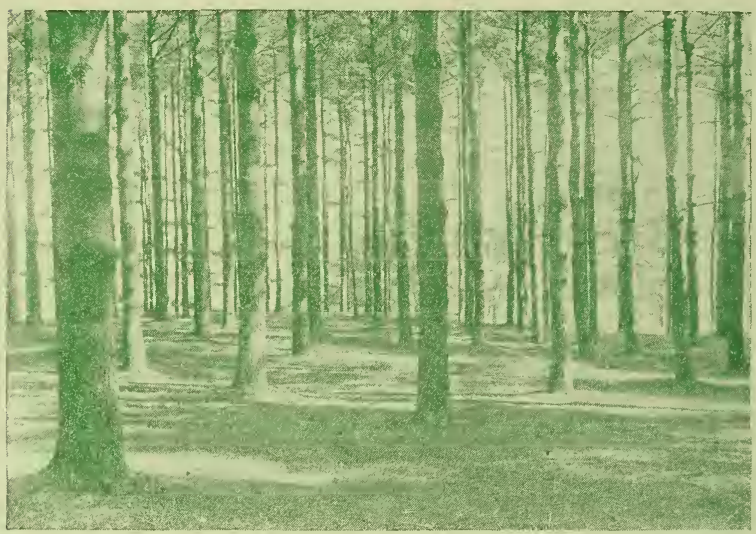

A Properly Thinned Forest Plantation

\section{Estimating, Surveying and Mapping}

We are well equipped to do this class of work also, and our maps include such data as experience has shown to be useful for any practical purpose to which it may be put, such as locating bounds, plantations, natural growth, rough topography, etc., and including also a fairly accurate estimate of the existing stand of timber.

Such maps, containing all the essentials of a good, useful plan, will be made at the following rates (exclusive of the timber estimate, for which special prices must be made) :-

$\begin{array}{rr}5 \text { to } 25 \text { acres } & \$ 1.00 \text { per acre } \\ 25 \text { " } 100 \text { " } & .75 \% \text { “" } \\ 100 \text { acres and upward } & .50 \text { “ }\end{array}$




\section{Nursery Stock}

\section{Location of Nursery}

Our nursery is located up in the hills of northwestern Massachusetts in the town of Colrain close to the Vermont line and not far from the famous Mohawk trail and on account of the elevation (1700 feet above sea level) our stock is very hardy.

\section{Visitors}

We are always glad to see visitors at the nursery and can assure them of a hearty welcome. Shelburne Falls on the Fitchburg Division of the Boston and Maine Railroad is the nearest railway point.

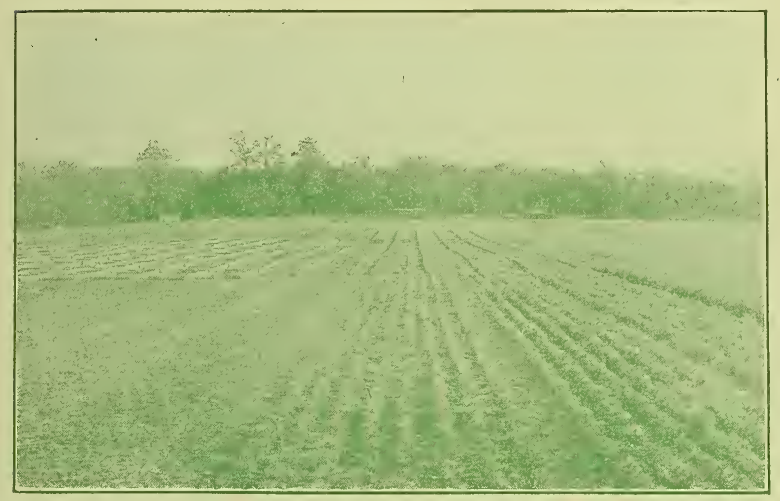

General View of Nursery

\section{Variety of Species and Listing}

We confine ourselves chiefly to the species listed on the following page as being those best adapted to forest planting, though we raise a few others for ornamental and special purposes.

We are proud of the root-systems of our trees, and raise all our stock with the least possible application of fertilizer and water, as it is our belief that trees so grown are better able to resist rigorous conditions after planting, and in this we feel that we know what we are about, for we plant large numbers every year and guarantee them. 


\section{Nursery Stock Prices 1917}

\section{Conifers}

$\begin{array}{llllll}\text { White Pine (Pinus strobus) } 500 & 1,000 & 10,000 & 100,000\end{array}$

3-year Transplants (3 to 8 in.) $\quad \$ 4.00 \quad \$ 6.00 \$ 57.50 \$ 500.00$

4-year Transplants (6 to 10 in.) $\quad 6.00 \quad 10.00 \quad 90.00$

5-year Transplants (6 to 14 in.) $12.00 \quad 20.00$

6 -year Transplants (12 to 24 in.)

7-year Transplants (18 to 30 in.)

SSpecial, twice transplanted $\{10$ cents each

Special, twice transplanted $\left\{\begin{array}{r}15 \text { cents each } \\ \text { Special }\end{array}\right.$

RedPine (Pinus resinosa)

3-year Transplants ( 3 to 7 in.) $\quad 4.00 \quad 6.00 \quad 57.50$

4-year Transplants (6 to $10 \mathrm{in.}) \quad 6.00 \quad 10.00 \quad 90.00$

5-year Transplants (6 to 12 in.) $12.00 \quad 20.00$

Scotch Pine (Pinus sylvestris)

3-year Transplants (4 to 8 in.) $\quad 4.00 \quad 6.00 \quad 57.50$

4-year Transplants (12 to 15 in.) $6.00 \quad 10.00 \quad 90.00$

5-year Transplants (18 to 24 in.) 12.0020 .00

Austrian Pine (Pinus austriaca)

3-year Transplants ( 4 to 6 in.) $\quad 4.00 \quad 6.00$

Pitch Pine (Pinus rigida)

3-year Transplants ( 4 to 8 in.) $\quad 4.00 \quad 6.00$

Balsam Fir (Abies balsamea)

4-year Transplants ( 3 to 7 in.) $\quad 6.00 \quad 10.00$

Arborvitae (Thuya occidentalis)

3-year Transplants ( 2 to $4 \mathrm{in}$.) $\quad 4.00$

4-year Transplants ( 3 to 6 in.) 6.00

Norway Spruce (Picea excelsa)

3-year Transplants (3 to 6 in.) $\quad 4.00 \quad 6.00 \quad 57.50$

Blue or Colorado Spruce (Picea pungens)

8-year Transplants (20 to 40 in.) $\quad\{$ Special, $3 \times$ transplanted

$\left\{\begin{array}{r}\text { sents each } \\ 40 \text { cecian }\end{array}\right.$

European Larch (Larix europea)

4-year Transplants (6 to 12 in.) $6.00 \quad 10.00$

Jack Pine (Pinus banksiana)

5-year Transplants (20 to 30 in.) $12.00 \quad 20.00190 .00$

\section{Broad Leaf Trees}

White Ash (Fraxinus americana)

4-year Seedlings (18 to 24 in.) $\quad 6.00 \quad 10.00 \quad 90.00$

4-year Transplants (18 to 24 in.) 12.0020 .00 
Prices on nursery stock given on page 8 are net, F. O. B. Lyonsville, Franklin County, Massachusetts, packing included, and are subject to nol discounts whatsoever.

All stock is listed subject to previous sale.

While we do not guarantee our stock when not planted by us, we use every effort to satisfy and please our customers, and if notified within 5 days of any unsatisfactory shipment received from our nurseries we will either make it right or take the stock back.

No order for less than 500 trees of a species will be accepted, even though the whole amount of stock ordered should total 500 . 


\section{PREPAREDNESS!}

You believe in it against other dangers;

why not against a

TIMBER FAMINE?

casposes?

(5) 